\title{
PENGELOMPOKKAN JUMLAH DESA/KELURAHAN YANG MEMILIKI SARANA KESEHATAN MENURUT PROVINSI DENGAN MENGGUNAKAN METODE K-MEANS CLUSTER
}

\author{
Dwi Retno Sekar Mayangsari' ${ }^{1}$, Solikhun ${ }^{2}, \operatorname{Irawan}^{3}$ \\ ${ }^{1}$ Mahasiswa STIKOM Tunas Bangsa, Pematangsiantar, Indonesia \\ ${ }^{2,3}$ Dosen STIKOM Tunas Bangsa, Pematangsiantar, Indonesia \\ Email: ${ }^{1}$ dwiretnosekar25@gmail.com, ${ }^{2}$ Solikhun@amiktunasbangsa.ac.id, \\ 3rawaniwan56@amiktunasbangsa.ac.id
}

\begin{abstract}
Abstrak
Masalah kesehatan yang ada di dalam masyarakat terutama di negara- negara berkembang seperti Indonesia dipengaruhi oleh dua faktor yaitu aspek fisik dan aspek non fisik. Aspek fisik seperti sarana kesehatan dan pengobatan penyakit, sedangkan yang kedua adalah aspek non fisik yang menyangkut masalah kesehatan. Pembangunan sarana kesehatan merupakan upaya pemenuhan salah satu hak dasar rakyat yang dilakukan oleh pemerintah untuk menyediakan fasilitas kesehatan yang akan digunakan dalam membantu masyarakat untuk menjadi sehat. Maka tujuan penelitian ini adalah untuk melakukan pengelompokkan terhadap desa/kelurahan yang memiliki sarana kesehatan dengan cepat dan efektif. Mendeskripsikan jumlah desa/kelurahan yang memiliki sarana kesehatan dengan menggunakan metode K-Means. Agar mengetahui apakah kendala yang dihadapi pemerintah dalam mengelompokkan desa/kelurahan yang memiliki sarana kesehatan yang tidak memadai berdasarkan provinsi yang ada di Indonesia dan membutuhkan waktu yang lama untuk mengelompokannya. Diharapkan dengan menggunakan metode ini dapat dihasilkan clustering yang terbukti akurat dalam kasus jumlah desa/kelurahan yang memiliki sarana kesehatan yang kurang memadai berdasarkan provinsi di indonesia.
\end{abstract}

Kata kunci: Sarana Kesehatan, Datamining, K-Means.

\begin{abstract}
Health problems that exist in the community, especially in developing countries such as Indonesia are influenced by two facto rs, namely physical aspects and non-physical aspects. Physical aspects such as health facilities and treatment of diseases, while the second is non-physical aspects that involve health problems. The construction of health facilities is an effort to fulfill one of the basic rights of the people carried out by the government to provide health facilities that will be used in helping the community to be healthy. So the purpose of this study is to group villages / kelurahan that have health facilities quickly and effectively. Describe the number of villages / kelurahan that have health facilities using the K-Means method, in order to find out whether the constraints faced by the government in grouping villages / kelurahan that have inadequate health facilities based on the provinces in Indonesia, require a long time to group them. It is expected that using this method can produce clustering which is proven to be accurate in the case of the number of villages / kelurahan that have inadequate health facilities based on the provinces in Indonesia.
\end{abstract}

Keywords: Health Facilities, Datamining, K-Means

\section{PENDAHULUAN}

Masalah kesehatan yang ada di dalam masyarakat terutama di negara- negara berkembang seperti Indonesia dipengaruh oleh dua faktor yaitu aspek fisik dan aspek non fisik. Aspek fisik seperti sarana kesehatan dan pengobatan penyakit, sedangkan yang kedua adalah aspek non fisik yang menyangkut masalah kesehatan[1]. Sarana kesehatan yang ada di Indonesia sangat perlu diperhatikan oleh pemerintah karena khususnya di desa/kelurahan masih tergolong kurang. Contohnya seperti puskesmas, rumah sakit, klinik, maupun tempat pengobatan lainnya. Sarana kesehatan yang tidak tercukupi di desa/kelurahan akan membuat masyarakat di desa tersebut kesulitan untuk hidup sehat dan mengobati penyakitnya. Seperti contoh jika ada ibu hamil yang ingin bersalin akan kesulitan apabila sarananya tidak memadai. Oleh sebab itu, pemerintah diharapkan dapat memperbaiki kondisi sarana kesehatan yang kurang di desa/kelurahan yang ada di provinsi Indonesia. Tetapi, adanya kendala bagi pemerintah untuk mengelompokkan desa/kelurahan yang memiliki sarana tidak memadai berdasarkan provinsi yang ada di Indonesia yaitu membutuhkan waktu untuk mengelompokannya. Oleh sebab itu, penelitian ini bertujuan untuk melakukan pengelompokkan terhadap desa/kelurahan yang memiliki sarana kesehatan dengan cepat dan efektif.

\section{METODOLOGI PENELITIAN}

\subsection{Data Mining}

Data Mining merupakan proses maupun kegiatan mengumpulkan sekumpulan data dalam jumlah yang besar untuk di ekstraksi sehingga menjadi informasi yang dapat digunakan[2]. Data mining adalah proses yang menggunakan teknik statistik, matematika, kecerdasan buatan, dan machine learning untuk mengekstraksi dan mengidentifikasi informasi yang bermanfaat dan pengetahuan yang terkait dari database yang besar. Tujuan utama 
data mining adalah untuk menemukan, menggali, atau menambang pengetahuan dari data atau informasi yang kita miliki [3].

\subsection{Cluster}

Menurut Baskoro cluster atau klusterisasi adalah salah satu alat bantu pada data mining yang bertujuan mengelompokkan objek-objek ke dalam cluster - cluster. Cluster adalah metode penganalisaan data, yang sering dimasukkan sebagai salah satu metode Data mining, yang tujuannya adalah untuk mengelompokkan data dengan karakteristik yang sama ke suatu wilayah yang sama dan data dengan karakteristik yang berbeda ke wilayah yang lain [4]. Cluster berbeda dari klasifikasi karena cluster tidak memiliki variabel target. Tujuan cluster bukan untuk mengklasifikasikan, memperkirakan, atau memprediksi nilai variabel taget.

\section{3. $K$-Means}

K-Means merupakan suatu algoritma yang digunakan dalam pengelompokkan secara pertisi yang memisahkan data ke dalam kelompok yang berbeda-berda. Algoritma ini mampu meminimalkan jarak antara data ke cluster nya [5].

Secara umum algoritma $K$-Means memiliki langkah-langkah dalam pengelompokan

1. Inisilisasi: menentukan nilai $K$ centroid yang diinginkan dan metrik ketidakmiripan (jarak) yang diinginkan.

2. Memilih $K$ data dari set $X$ sebagai centroid. Untuk menentukan centroid dapat menggunakan persamaan. Jumlah Data

$\overline{\text { Jumlah Class }+1}$

3. Mengalokasikan semua data ke centroid terdekat dengan matrik jarak yang telah ditetapkan.

4. Menghitung kembali centroid $C$ berdasarkan data yang mengikuti cluster masing - masing.

5. Mengulangi langkah 3 dan 4 hingga kondisi konvergen tercapai.

Berikut ini adalah rumus untuk menentukan jumlah cluster:

$\mathrm{K}=\sqrt{\frac{N}{2}}$

Keterangan:

$\mathrm{K}=$ klaster

$\mathrm{N}=$ jumlah data

Menghitung jarak pada ruang jarak Euclidean menggunakan formula:

$D\left(x_{2}, x_{1}\right)=\left\|x_{2}-x_{1}\right\|_{2}$

$\sqrt{\sum_{j=1}^{p}\left|x_{2 j}-x_{1 j}\right|^{2}}$

Keterangan:

$D=$ euclidean distance

$x=$ banyaknya objek

$\sum^{P}=$ jumlah data record

\section{ANALISA DAN PEMBAHASAN}

\subsection{Tahap Analisis}

Metode analisis data terdiri atas dua macam, yaitu metode statistik deskriptif dan metode statistik inferensial. Jika pada metode penelitian penulis menggunakan metode penelitian kuantitatif, maka metode analisa data yang penulis gunakan adalah metode statistik inferensial. Proses analisa data dapat dilakukan setelah adanya pengumpulan data yang bersifat valid. Dalam melakukan penelitian ini, penulis melakukan analisa data statistik bersifat sekunder yang dimana data diperoleh tidak dari sumbernya langsung, melainkan sudah dikumpulkan dan diolah secara terinci yang dimana data berkaitan dengan permasalahan yang sedang diteliti.

Data yang digunakan terdiri dari 6 parameter yaitu:

1. Rumah Sakit

2. Rumah Sakit Bersalin

3. Poliklinik

4. Puskesmas

5. Puskesmas Pembantu

6. Apotek 


\begin{tabular}{|c|c|c|c|c|c|c|c|c|c|c|c|c|c|c|c|c|c|c|}
\hline \multirow{3}{*}{ Provinsi } & \multicolumn{18}{|c|}{ Jumlah Desa/Kelurahan Yang Memilili Sarana Kesehatan Menurut Proviusi } \\
\hline & \multicolumn{3}{|c|}{ Rumah Salit } & \multicolumn{3}{|c|}{$\begin{array}{c}\text { Rumah Salat } \\
\text { Bersalin }\end{array}$} & \multicolumn{3}{|c|}{ Polildinilk } & \multicolumn{3}{|c|}{ Puskesmas } & \multicolumn{3}{|c|}{ Puskesmas Pembantu } & \multicolumn{3}{|c|}{ Apotel } \\
\hline & 2008 & 2011 & 2014 & 2008 & 2011 & 2014 & 2008 & 2011 & 2014 & 2008 & 2011 & 2014 & 2008 & 2011 & 2014 & 2005 & 2011 & 2014 \\
\hline Aceh & 40 & 53 & 64 & 40 & 60 & 50 & 172 & 155 & 210 & 305 & 322 & 353 & 343 & 963 & 981 & 162 & 212 & 239 \\
\hline Sumatera Utara & 152 & 171 & 178 & 354 & 258 & 192 & 859 & 735 & 872 & 513 & 535 & 535 & 1798 & 1757 & 1858 & 373 & 439 & 573 \\
\hline Sumatera Barat & 39 & 45 & 48 & 117 & 111 & 63 & 83 & 35 & 98 & 241 & 230 & 274 & 573 & 623 & 691 & 114 & 150 & 201 \\
\hline Riau & 41 & 45 & 59 & 96 & 99 & 76 & 220 & 215 & 265 & 187 & 201 & 229 & 805 & 798 & 913 & 136 & 156 & 261 \\
\hline Jambi & 23 & 28 & 35 & 40 & 46 & 32 & 50 & 30 & 62 & 158 & 173 & 196 & 395 & 531 & 635 & 71 & $\$ 2$ & 130 \\
\hline Sumatera Selatan & 38 & 48 & 39 & 78 & 79 & 57 & 138 & 109 & 134 & 252 & 296 & 350 & 914 & 797 & 911 & 102 & 146 & 171 \\
\hline Bengkulu & 15 & 16 & 18 & 10 & 11 & 8 & 33 & 25 & 30 & 156 & 190 & 177 & 457 & 403 & 444 & 57 & 70 & 97 \\
\hline Lampung & 31 & 37 & 46 & 162 & 159 & 100 & 253 & 265 & 312 & 259 & 273 & 320 & 731 & 757 & 333 & 113 & 164 & 226 \\
\hline Kep Bangka Belitung & 10 & 13 & 16 & 10 & 21 & 60 & 24 & 24 & 33 & 56 & 58 & 62 & 156 & 154 & 163 & 27 & 42 & 55 \\
\hline Kep Rial & 18 & 22 & 25 & 40 & 36 & 21 & 50 & 38 & 64 & 35 & 68 & 77 & 200 & 187 & 224 & 56 & 63 & 77 \\
\hline DKI Jakarta & 92 & 97 & 99 & 183 & 159 & 140 & 240 & 233 & 236 & 241 & 246 & 249 & - & - & - & 241 & 249 & 246 \\
\hline Jawa Barat & 177 & 205 & 244 & 392 & 548 & 341 & 1449 & 1355 & 1499 & 1010 & 1029 & 1074 & 1624 & 1523 & 1835 & 900 & 1099 & 1396 \\
\hline Jawa Tengah & 205 & 231 & 247 & 659 & 796 & 428 & 1259 & 520 & 1035 & 961 & 966 & 831 & 1831 & 1905 & 1523 & 393 & 1223 & 1553 \\
\hline DI Yogyakarta & 41 & 47 & 55 & 97 & 34 & 59 & 119 & 140 & 146 & 120 & 120 & 121 & 310 & 304 & 306 & 119 & 155 & 174 \\
\hline Jawa Tinur & 219 & 243 & 274 & 486 & 556 & 307 & 715 & 720 & 873 & 951 & 951 & 987 & 2253 & 2211 & 22327 & 376 & 1125 & 1424 \\
\hline Banten & 39 & 52 & 60 & 164 & 155 & 111 & 427 & 383 & 445 & 192 & 218 & 233 & 263 & 246 & 279 & 190 & 248 & 313 \\
\hline Bali & 30 & 35 & 39 & 42 & 49 & 26 & 36 & 50 & 57 & 114 & 115 & 119 & 452 & 441 & 487 & 125 & 141 & 160 \\
\hline Nusa Tengrara Barat & 17 & 17 & 22 & 20 & 13 & 11 & 26 & 32 & 55 & 137 & 151 & 165 & 500 & 509 & 532 & 34 & 114 & 147 \\
\hline Nusa Tengaga Timur & 30 & 36 & 40 & 19 & 21 & 16 & 102 & 96 & 99 & 281 & 333 & 377 & 954 & 393 & 990 & 65 & 87 & 113 \\
\hline Ralimantan Barat & 25 & 27 & 35 & 29 & 33 & 18 & 63 & 51 & 81 & 220 & 233 & 258 & 768 & 691 & 506 & 51 & 65 & 34 \\
\hline Kalimantan Tengah & 17 & 17 & 17 & 16 & 14 & 7 & 53 & 38 & 74 & 176 & 178 & 200 & 505 & 864 & 993 & 38 & 42 & 59 \\
\hline Kalimantah Selatan & 23 & 26 & 27 & 17 & 17 & 12 & 75 & 31 & 94 & 209 & 223 & 234 & 597 & 507 & 505 & 68 & 83 & 118 \\
\hline Kalimantan Timur & 33 & 39 & 31 & 26 & 37 & 31 & 86 & 90 & 113 & 209 & 212 & 193 & 673 & 683 & 694 & 91 & 121 & 147 \\
\hline Kalimantan Utara & - & - & 7 & - & - & 2 & - & - & 13 & - & - & 50 & - & - & 176 & - & - & 32 \\
\hline Sulawesi Utra & 27 & 32 & 35 & 37 & 34 & 27 & 38 & 37 & 53 & 148 & 172 & 212 & 439 & 429 & 508 & 75 & 102 & 111 \\
\hline Sulawesi Tengah & 19 & 20 & 20 & 13 & 14 & 10 & 24 & 24 & 34 & 160 & 171 & 152 & 678 & 631 & 676 & 63 & $\$ 2$ & 122 \\
\hline Sulawesi Selatan & 49 & 60 & 63 & 74 & 76 & 70 & 118 & 109 & 134 & 406 & 419 & 447 & 1265 & 1207 & 1324 & 228 & 269 & 323 \\
\hline Sulawesi Tengagara & 21 & 24 & 22 & 7 & 17 & 11 & 16 & 16 & 25 & 187 & 242 & 266 & 496 & 393 & 474 & 38 & 75 & 109 \\
\hline Gorontalo & 8 & 10 & 12 & 9 & 4 & 1 & 28 & 8 & 9 & 78 & 33 & 96 & 226 & 187 & 224 & 30 & 48 & 66 \\
\hline Sulawesi Barat & 7 & 8 & 8 & 2 & 1 & 1 & 12 & 2 & 12 & 75 & 33 & 93 & 267 & 200 & 239 & 17 & 23 & 28 \\
\hline Maluku & 20 & 20 & 27 & 5 & 5 & 6 & 30 & 16 & 31 & 150 & 160 & 183 & 394 & 337 & 438 & 30 & 37 & 51 \\
\hline Maluku Utara & 13 & 16 & 17 & 1 & 3 & 1 & 9 & 9 & 14 & 91 & 112 & 130 & 203 & 190 & 263 & 25 & 45 & 62 \\
\hline Papua Barat & 11 & 13 & 14 & 7 & 6 & 2 & 35 & 29 & 30 & 97 & 124 & 144 & 352 & 298 & 434 & 28 & 39 & 58 \\
\hline Papua & 26 & 30 & 43 & 12 & 12 & 10 & 248 & 74 & 134 & 245 & 273 & 396 & 649 & 606 & 983 & 51 & 75 & 91 \\
\hline
\end{tabular}

Gambr 1. Data BPS/Penelitian

(Sumber :Data Badan Pusat Statistik Nasional, Tahun 2008-2014)

\subsection{Perhitungan Manual}

Untuk mendapatkan hasil dari penelitian yang dilakukan, berikut uraian perhitungan manual proses clustering desa/kelurahan yang memiliki sarana kesehatan menggunakan algoritma K-Means. Proses clustering dilakukan mulai dari penentuan data yang ingin di cluster. Dalam hal ini variabel data yang ingin di cluster adalah data dari tahun 2008 sampai 2014 dan disini peneliti mengambil nilai rata rata dari tahun 2008 sampai 2014 sebagai data yang akan di cluster. Berikut adalah langkah-langkah penyelesaian yang dilakukan penulis dalam mengelompokkan Desa/Kelurahan yang Meiliki sarana Kesehatan menggunakan algoritma K-Means :

1. Menentukan jumlah data yang akan di cluster, dimana sampel data desa/kelurahan yang memiliki sarana kesehatan yang akan digunakan dalam proses clustering adalah data jumlah persentase desa/kelurahan yang memiliki sarana kesehatan terdapat pada Badan Pusat Statistik pada tahun 2008-2014 dengan jumlah data sebanyak 34 Provinsi.

2. Menetapkan nilai $\mathrm{k}$ jumlah cluster jumlah desa/kelurahan yang memiliki sarana kesehatan sebanyak 3 cluster (k3). Cluster yang dibentuk yaitu cluster tertinggi, cluster sedang, dan cluster terendah.

3. Menentukan nilai centroid (pusat cluster) awal yang telah ditentukan secara random berdasarkan nilai variabel data yang di cluster sebanyak k yang ditentukan sebelumnya. Adapun cluster tertinggi diperoleh dari nilai tertinggi pada tabel 2, cluster sedang diambil dari nilai rata-rata pada tabel 2, dan cluster terendah diambil dari nilai terkecil pada tabel 2. Berikut adalah tabel penentuan centroid awal tiap cluster.

Tabel 2. Centroid Data Awal (Iterasi 1)

\begin{tabular}{lcccccc}
\hline CLUSTER & A & B & C & D & E & F \\
\hline MAX & 245,33 & 624,33 & 1434,33 & 1037,67 & 2263,67 & 1223,00 \\
AVERAGE & 52,40 & 89,16 & 202,35 & 270,08 & 687,86 & 211,67 \\
MIN & 2,33 & 0,67 & 4,33 & 16,67 & 0,00 & 10,67 \\
\hline
\end{tabular}

4. Menghitung jarak setiap data desa/kelurahan yang memiliki sarana kesehatan terhadap pusat cluster. Setelah data nilai pusat cluster awal ditentukan, maka langkah selanjutnya adalah menghitung jarak masing-masing data terhadap pusat cluster dengan menggunakan rumus yang perhitungannya dapat kita lihat sebagai berikut:

Dilakukan perhitungan jarak terhadap data desa/kelurahan yang memiliki sarana kesehatan dengan titik pusat (centroid) pada cluster pertama.

$\mathrm{D}(1.1)=\sqrt{\left(\begin{array}{c}(245,33-52,33)^{2}+(624,33-50,00)^{2}+(1434,33-179,00)^{2}+ \\ (1037,67-326,67)^{2}+(2263,67-895,67)^{2}+(1223,00-204,33)^{2}\end{array}\right.}=2314,65$ 
$\mathrm{D}(1.2)=\sqrt{\frac{(245,33-167,00)^{2}+(624,33-268,00)^{2}+(1434,33-822,00)^{2}+}{(1037,67-544,33)^{2}+(2263,67-1804,33)^{2}+(1223,00-461,67)^{2}}}=1241,80$

Dan seterusnya sampai dengan $\mathrm{D}(1.34)$

Perhitungan jarak desa/kelurahan yang memiliki sarana kesehatan pertama dengan centroid cluster kedua, seperti berikut:

$$
\begin{aligned}
& D(2.1)=\sqrt{\begin{array}{c}
(52,40-52,33)^{2}+(89,16-50,00)^{2}+(202,35-179,00)^{2}+ \\
(270,08-326,67)^{2}+(687,86-895,67)^{2}+(211,67-204,33)^{2}
\end{array}}=220,27 \\
& D(2.2)=\sqrt{\begin{array}{c}
(52,40-167,00)^{2}+(89,16-268,00)^{2}+(202,35-822,00)^{2}+ \\
(270,08-544,33)^{2}+(687,86-1804,33)^{2}+(211,67-461,67)^{2}
\end{array}}=1346,59
\end{aligned}
$$

Dan seterusnya sampai dengan $\mathrm{D}(2.34)$

Perhitungan jarak desa/kelurahan yang memiliki sarana kesehatan pertama dengan centroid cluster ketiga, seperti berikut:

$$
\begin{aligned}
& D(3.1)=\sqrt{\begin{array}{c}
(2,33-52,33)^{2}+(0,67-50,00)^{2}+(4,33-179,00)^{2}+ \\
(16,67-326,67)^{2}+(0,00-895,67)^{2}+(10,67-204,33)^{2}
\end{array}}=985,53 \\
& D(3.2)=\sqrt{\begin{array}{c}
(2,33-167,00)^{2}+(0,67-268,00)^{2}+(4,33-822,00)^{2}+ \\
(16,67-544,33)^{2}+(0,00-1804,33)^{2}+(10,67-461,67)^{2}
\end{array}}=2122,41
\end{aligned}
$$

\begin{tabular}{|c|c|c|c|c|c|c|c|c|c|c|}
\hline \multirow{2}{*}{ Provinsi } & \multicolumn{6}{|c|}{$\begin{array}{c}\text { Jumlah Desa/Kelurahan Yang Memiliki Sarana Kesehatan Menurut } \\
\text { Provinsi }\end{array}$} & \multirow[t]{2}{*}{$\mathrm{Cl}$} & \multirow[t]{2}{*}{$\mathrm{C} 2$} & \multirow[t]{2}{*}{$\mathrm{C} 3$} & \multirow{2}{*}{$\begin{array}{c}\text { ITERASI } 1 \\
\text { JARAK TERPENDEK }\end{array}$} \\
\hline & a & b & c & $d$ & $\mathrm{e}$ & $\mathrm{f}$ & & & & \\
\hline Aceh & 52,33 & 50,00 & 179,00 & 326,67 & 895,67 & 204,33 & 2314,65 & 220,27 & 985,53 & 220,27 \\
\hline Sumatera Utara & 167,00 & 268,00 & 822,00 & 544,33 & 1804,33 & 461,67 & 1241,80 & 1346,59 & 2122,41 & 1241,80 \\
\hline Sumatera Barat & 44,00 & 97,00 & 88,67 & 255,00 & 629,00 & 155,00 & 2560,23 & 141,28 & 701,00 & 141,28 \\
\hline Riau & 48,33 & 90,33 & 233,33 & 205,67 & 839,00 & 184,33 & 2359,47 & 169,46 & 912,36 & 169,46 \\
\hline Jambi & 28,67 & 39,33 & 47,33 & 175,67 & 593,67 & 94,33 & 2668,10 & 242,14 & 623,51 & 242,14 \\
\hline Sumatera Selatan & 48,33 & 71,33 & 127,00 & 309,33 & 874,00 & 139,67 & 2385,16 & 217,68 & 942,51 & 217,68 \\
\hline Bengkulu & 16,33 & 9,67 & 29,33 & 171,00 & 434,67 & 74,67 & 2796,30 & 360,90 & 466,64 & 360,90 \\
\hline Lampung & 38,00 & 140,33 & 276,67 & 284,00 & 790,33 & 167,67 & 2338,78 & 144,84 & 903,15 & 144,84 \\
\hline Kep. Bangka Belitung & 13,00 & 30,33 & 27,00 & 58,67 & 157,67 & 41,33 & 3029,42 & 624,96 & 170,50 & 170,50 \\
\hline Kep. Riau & 21,67 & 32,33 & 50,67 & 66,67 & 203,67 & 65,33 & 2973,49 & 569,58 & 224,70 & 224,70 \\
\hline DKI Jakarta & 96,00 & 160,67 & 236,33 & 245,33 & 0,00 & 245,33 & 2894,88 & 695,03 & 442,22 & 442,22 \\
\hline Jawa Barat & 208,67 & 427,00 & 1434,33 & 1037,67 & 1660,67 & 1118,33 & 644,09 & 2003,48 & 2701,19 & 644,09 \\
\hline Jawa Tengah & 227,67 & 624,33 & 1048,00 & 869,33 & 1836,33 & 1223,00 & 600,43 & 1932,13 & 2664,19 & 600,43 \\
\hline DI Yogyakarta & 47,67 & 80,00 & 135,00 & 120,33 & 306,67 & 149,33 & 2801,38 & 419,84 & 386,58 & 386,58 \\
\hline Jawa Timur & 245,33 & 449,67 & 769,33 & 963,00 & 2263,67 & 1141,67 & 696,36 & 2077,70 & 2853,90 & 696,36 \\
\hline Banten & 50,33 & 143,33 & 420,00 & 214,33 & 262,67 & 250,33 & 2631,77 & 485,49 & 600,78 & 485,49 \\
\hline Bali & 34,67 & 39,00 & 47,67 & 116,00 & 460,00 & 142,00 & 2753,38 & 327,53 & 493,06 & 327,53 \\
\hline Nusa Tenggara Barat & 18,67 & 14,67 & 37,67 & 151,00 & 513,67 & 115,00 & 2729,49 & 296,10 & 542,55 & 296,10 \\
\hline Nusa Tenggara Timur & 35,33 & 18,67 & 99,00 & 330,33 & 942,33 & 88,33 & 2393,27 & 315,50 & 1001,39 & 315,50 \\
\hline Kalimantan Barat & 29,00 & 26,67 & 66,67 & 237,00 & 755,00 & 66,67 & 2555,15 & 222,46 & 791,82 & 222,46 \\
\hline Kalimantan Tengah & 17,00 & 12,33 & 55,00 & 184,67 & 887,67 & 46,33 & 2516,90 & 321,59 & 905,74 & 321,59 \\
\hline Kalimantan Selatan & 25,33 & 15,00 & 83,33 & 222,00 & 536,33 & 91,33 & 2678,53 & 245,26 & 585,92 & 245,26 \\
\hline Kalimantan Timur & 34,33 & 31,33 & 96,33 & 204,67 & 681,67 & 119,67 & 2569,12 & 166,41 & 722,72 & 166,41 \\
\hline Kalimantan Utara & 2,33 & 0,67 & 4,33 & 16,67 & 58,67 & 10,67 & 3141,20 & 741,66 & 58,67 & 58,67 \\
\hline Sulawesi Utara & 31,33 & 32,67 & 49,33 & 177,33 & 458,67 & 96,00 & 2753,62 & 318,69 & 497,35 & 318,69 \\
\hline Sulawesi Tengah & 19,67 & 12,33 & 27,33 & 171,00 & 661,67 & 89,00 & 2647,37 & 251,31 & 684,63 & 251,31 \\
\hline Sulawesi Selatan & 57,33 & 73,33 & 120,33 & 424,00 & 1265,33 & 273,33 & 2083,43 & 606,60 & 1362,99 & 606,60 \\
\hline Sulawesi Tenggara & 22,33 & 11,67 & 19,00 & 231,67 & 454,33 & 74,00 & 2769,80 & 339,84 & 507,34 & 339,84 \\
\hline
\end{tabular}

Dan seterusnya sampai dengan $\mathrm{D}(3.34)$

Berikut tabel 3.3 hasil perhitungan jarak data dengan titik pusat pada iterasi 1 menggunakan Eulidean Distance.

Gambar 2. Hasil Perhitungan Jarak Data ke Titik Pusat Pada Cluster

5. Menentukan posisi cluster masing-masing data desa/kelurahan yang memiliki sarana kesehatan berdasarkan jarak minimum data terhadap pusat cluster. Data yang memiliki jarak terkecil dengan centroid akan menjadi anggota pada kelompok tersebut. Berikut ini merupakan tabel 3.4 posisi data dengan tiap cluster pada iterasi ke-1 dengan menggunakan bantuan tanda (1) yang mengatakan data menjadi anggota pada cluster.

Tabel 4. Posisi data hasil pengelompokan tiap cluster pada iterasi ke-1

Provinsi

C1 1 C2 2 C3

\begin{tabular}{lll}
\hline Aceh & & 1 \\
Sumatera Utara & 1 &
\end{tabular}




\begin{tabular}{|c|c|c|c|}
\hline Provinsi & C1 & C2 & C3 \\
\hline Sumatera Barat & & 1 & \\
\hline Riau & & 1 & \\
\hline Jambi & & 1 & \\
\hline Sumatera Selatan & & 1 & \\
\hline Bengkulu & & 1 & \\
\hline Lampung & & & 1 \\
\hline Kep. Bangka & & & 1 \\
\hline Kepulauan Riau & & & 1 \\
\hline DKI Jakarta & & & 1 \\
\hline Jawa Barat & 1 & & \\
\hline Jawa Tengah & 1 & & \\
\hline DI Yogyakarta & & & 1 \\
\hline Jawa Timur & 1 & & \\
\hline Banten & & 1 & \\
\hline Bali & & 1 & \\
\hline Nusa Tenggara Barat & & 1 & \\
\hline Nusa Tenggara Timur & & 1 & \\
\hline Kalimantan Barat & & 1 & \\
\hline Kalimantan Tengah & & 1 & \\
\hline Kalimantan Selatan & & 1 & \\
\hline Kalimantan Timur & & 1 & \\
\hline Kalimantan Utara & & & 1 \\
\hline Sulawesi Utara & & 1 & \\
\hline Sulawesi Tengah & & 1 & \\
\hline Sulawesi Selatan & & 1 & \\
\hline Sulawesi Tenggara & & 1 & \\
\hline Gorontalo & & & 1 \\
\hline Sulawesi Barat & & & 1 \\
\hline Maluku & & 1 & \\
\hline Maluku Utara & & & 1 \\
\hline Papua Barat & & & 1 \\
\hline Papua & & 1 & \\
\hline Jumlah & 4 & 20 & 10 \\
\hline
\end{tabular}

6. Menghitung titik pusat baru menggunakan hasil dari setiap anggota pada masing-masing cluster Contoh perhitungan titik pusat baru pada cluster $\mathrm{a}, \mathrm{b}, \mathrm{c}, \mathrm{d}$, e dan f adalah:

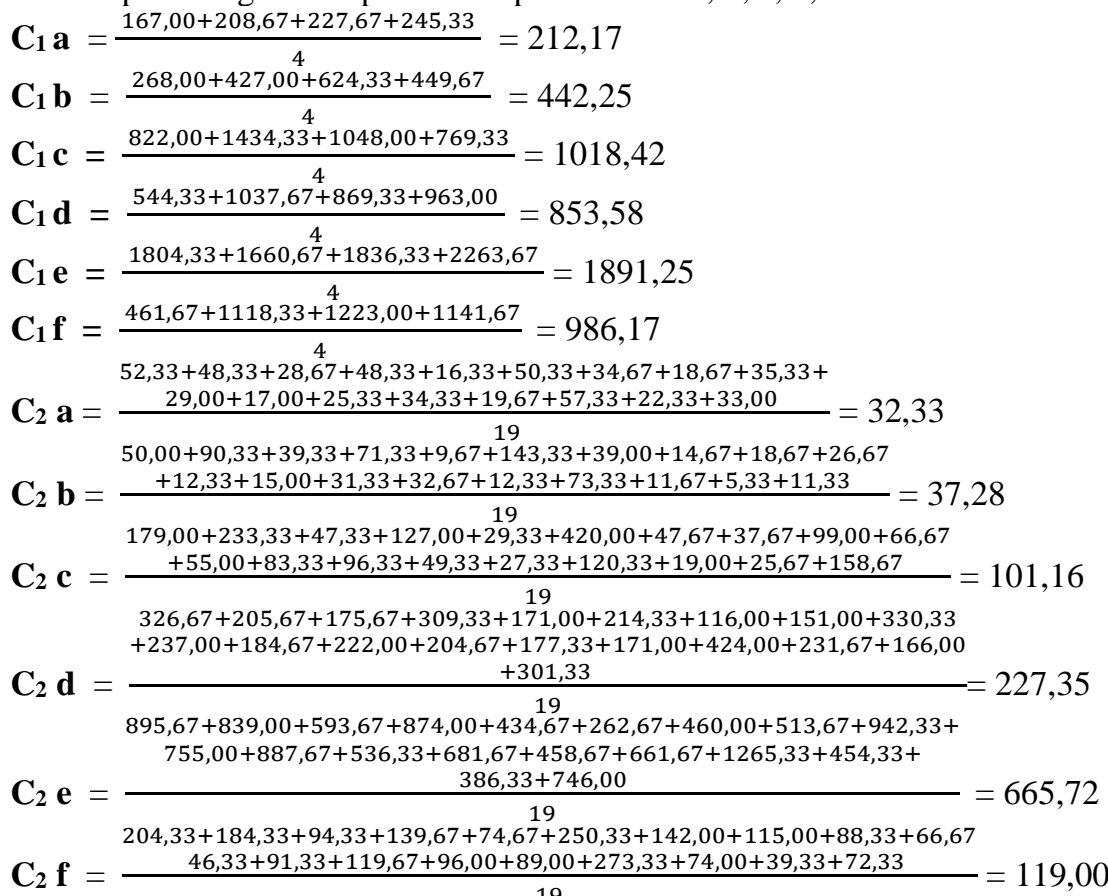




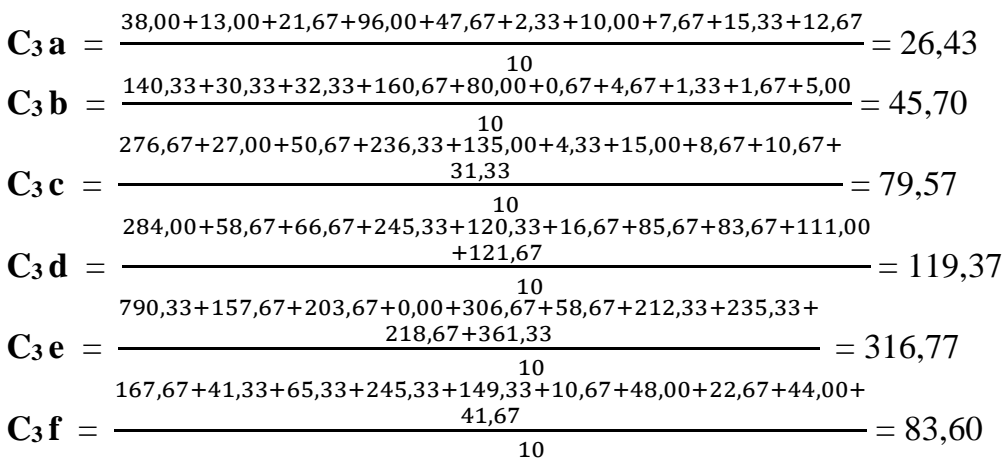

Berikut tabel 5. hasil perhitungan cluster baru pada iterasi 1

Tabel 5. Perhitungan Cluster Iterasi 1

\begin{tabular}{ccccccc}
\hline CLUSTER & A & B & C & D & E & F \\
\hline $\mathbf{C}_{\mathbf{1}}$ & 212,17 & 442,25 & 1018,42 & 853,58 & 1891,25 & 986,17 \\
$\mathbf{C}_{\mathbf{2}}$ & 32,23 & 37,28 & 101,16 & 227,35 & 665,72 & 119,00 \\
$\mathbf{C}_{\mathbf{3}}$ & 26,43 & 45,70 & 79,57 & 119,37 & 316,77 & 83,60
\end{tabular}

7. Selanjutnya dilakukan kembali langkah 4 sampai 6. Jika nilai centroid hasil iterasi dengan nilai centroid sebelumnya bernilai sama atau nilai centroid sudah optimal serta posisi cluster data desa/kelurahan yang memiliki saran kesehatan tidak mengalami perubahan lagi maka proses iterasi berhenti. Namun jika nilai centroid tidak sama atau belum optimal serta posisi data desa/kelurahan yang memiliki saraan kesehatan masih berubah maka proses iterasi berlanjut pada iterasi berikutnya.

\section{Lanjut iterasi 2}

Tabel hasil cluster iterasi 1

Tabel 6. Pusat Cluster Iterasi 2

\begin{tabular}{ccccccc}
\hline CLUSTER & $\mathbf{A}$ & $\mathbf{B}$ & $\mathbf{C}$ & $\mathbf{D}$ & $\mathbf{E}$ & $\mathbf{F}$ \\
\hline $\mathbf{C}_{\mathbf{1}}$ & 212,17 & 442,25 & 1018,42 & 853,58 & 1891,25 & 986,17 \\
$\mathbf{C}_{\mathbf{2}}$ & 32,23 & 37,28 & 101,16 & 227,35 & 665,72 & 119,00 \\
$\mathbf{C}_{\mathbf{3}}$ & 26,43 & 45,70 & 79,57 & 119,37 & 316,77 & 83,60 \\
\hline
\end{tabular}

8. Setelah data nilai pusat cluster iterasi 1 didapat maka langkah selanjutnya adalah melakukan perhitungan jarak terhadap data desa/kelurahan yang memiliki sarana kesehatan dengan titik pusat (centroid) pada cluster pertama.

$\mathrm{D}(1.1)$

$$
\begin{aligned}
& =\sqrt{\begin{array}{l}
(212,17-52,33)^{2}+(442,25-50,00)^{2}+(1018,42-179,00)^{2}+ \\
(853,25-326,67)^{2}+(1891,25-895,67)^{2}+(986,17-204,33)^{2}
\end{array}}=1662,56 \\
& =\sqrt{\begin{array}{l}
(212,17-167,00)^{2}+(442,25-268,00)^{2}+(1018,42-822,00)^{2}+ \\
(853,25-544,33)^{2}+(1891,25-1804,33)^{2}+(986,17-461,67)^{2}
\end{array}}=670,28
\end{aligned}
$$

Dan seterusnya sampai dengan $\mathrm{D}(1.34)$

Perhitungan jarak desa/kelurahan yang memiliki sarana kesehatan pertama dengan centroid cluster kedua, seperti berikut:

$$
\begin{aligned}
& =\sqrt{\begin{array}{c}
(32,33-52,33)^{2}+(37,28-50,00)^{2}+(101,16-179,00)^{2}+ \\
(227,35-326,67)^{2}+(665,72-895,67)^{2}+(119,00-204,33)^{2}
\end{array}}=276,84 \\
& =\sqrt{\begin{array}{c}
(32,33-167,00)^{2}+(37,28-268,00)^{2}+(101,16-822,00)^{2}+ \\
(227,35-544,33)^{2}+(665,72-1804,33)^{2}+(119,00-461,67)^{2}
\end{array}}=1450,97
\end{aligned}
$$

Dan seterusnya sampai dengan $\mathrm{D}(2.34)$

Perhitungan jarak desa/kelurahan yang memiliki saran kesehatan pertama dengan centroid cluster ketiga, seperti berikut:

$\mathrm{D}(3.1)$

$$
=\sqrt{\begin{array}{c}
(26,43-52,33)^{2}+(45,70-50,00)^{2}+(79,57-179,00)^{2}+ \\
(119,37-326,67)^{2}+(316,77-895,67)^{2}+(83,60-204,33)^{2}
\end{array}}=635,02
$$




$$
=\sqrt{\begin{array}{c}
(26,43-167,00)^{2}+(45,70-268,00)^{2}+(79,57-822,00)^{2}+ \\
(119,37-544,33)^{2}+(316,77-1804,33)^{2}+(83,60-461,67)^{2}
\end{array}}=1776,73
$$

Dan seterusnya sampai dengan $\mathrm{D}(3.34)$

Berikut hasil perhitungan jarak data dengan titik pusat pada iterasi 2 menggunakan Euclidean Distance.

\begin{tabular}{|c|c|c|c|c|c|c|c|c|c|c|}
\hline \multirow[t]{2}{*}{ Protinsi } & \multicolumn{6}{|c|}{$\begin{array}{l}\text { Jumbh Desa Keluraban Yang Meniliki Sarana Kesehatan Menurut } \\
\text { Provinci }\end{array}$} & \multirow[t]{2}{*}{$\mathrm{Cl}$} & \multirow[t]{2}{*}{$\mathrm{C} 2$} & \multirow[t]{2}{*}{ C3 } & \multirow{2}{*}{$\begin{array}{l}\text { IIERASI } 2 \\
\text { JARAK IERPENDEK }\end{array}$} \\
\hline & a & b & c & d & e & f & & & & \\
\hline Sumatera Utara & 16700 & 268,00 & 82200 & 5433 & 100433 & 46167 & 670.28 & 14097? & 1776,73 & 67128 \\
\hline Sumatera Barnt & 400 & 9700 & 88,67 & 25500 & 629,00 & 155,00 & 1911,63 & 8525 & 32215 & 85,25 \\
\hline Sumatera Selatan & 4833 & 7133 & 127,0 & 399,33 & 87400 & {$[139,67$} & 173396 & 22937 & 59424 & 289,37 \\
\hline Benghuilu & 16,33 & 9,57 & 2933 & 17100 & 43467 & 767 & $21+992$ & 25437 & 143,42 & $1+3,42$ \\
\hline Lampung & 38,00 & 140,33 & 276,57 & 28400 & 790,53 & 167,67 & 1696,49 & 250,12 & 55351 & 250.12 \\
\hline Kep. Bangta Belining & 13,00 & 30,33 & 2700 & 58.67 & 15767 & 4133 & 2392,10 & 546,37 & 18429 & 18439 \\
\hline Kep. Ruan & 2167 & 3233 & 50.67 & 6667 & $293,6 ?$ & 6533 & 233590 & 49485 & 130.15 & 190,15 \\
\hline DIYograkarta & 4767 & 80,00 & 135,0 & 12033 & 306,67 & 14933 & 2165,18 & 380,13 & 95,52 & 9552 \\
\hline Jawa Timm & 245,33 & 49,67 & 769,33 & 963,00 & 2663,67 & $11+167$ & 48790 & 2191,43 & 251168 & 48790 \\
\hline Banten & 50,33 & 143,33 & 40000 & $21+33$ & 262,67 & 250,33 & 201892 & 541,39 & 40712 & 40712 \\
\hline Bali & 3467 & 3900 & 47,67 & 11600 & 460,00 & 14200 & 210751 & 241,08 & 150,33 & 155,33 \\
\hline Nasa Tenggan Barat & 18,67 & 1467 & 3767 & 15100 & 513.67 & 11500 & 2081,45 & 183.56 & 208,65 & 183,56 \\
\hline Nusa Tenggara Timur & 3533 & 18,67 & 99,00 & 33033 & 94233 & 88,33 & 174251 & 297,36 & 66110 & 297,36 \\
\hline $\mathrm{Ka}$ lmantan Barat & 2900 & $266 ?$ & 66,67 & 23700 & 755,00 & 6667 & 190494 & 110,07 & 45465 & 110,07 \\
\hline Talimantan Tencah & $17 \mathrm{nn}$ & 1933 & $550 \mathrm{n}$ & 1216 & $m a$ & 16.32 & 13670 & 21267 & $\sin$ in & 71267 \\
\hline
\end{tabular}

Gambar 3. Hasil Perhitungan Jarak Data ke Titik Pusat Pada Cluster

Lanjut iterasi ke-3 :

Tabel hasil pusat cluster iterasi 3

Tabel 8. pusat cluster iterasi 4

\begin{tabular}{ccccccc}
\hline CLUSTER & $\mathbf{A}$ & $\mathbf{B}$ & $\mathbf{C}$ & $\mathbf{D}$ & $\mathbf{E}$ & $\mathbf{F}$ \\
\hline $\mathbf{C}_{\mathbf{1}}$ & 212,17 & 442,25 & 1018,42 & 853,58 & 1891,25 & 986,17 \\
$\mathbf{C}_{\mathbf{2}}$ & 37,77 & 52,08 & 125,49 & 266,18 & 802,77 & 131,03 \\
$\mathbf{C}_{\mathbf{3}}$ & 26,00 & 34,43 & 69,12 & 135,76 & 316,84 & 91,10 \\
\hline
\end{tabular}

\section{Lanjut iterasi ke-4}

Berikut tabel 3.6 hasil perhitungan cluster baru pada iterasi 4

Tabel 9. Perhitungan Cluster Iterasi 4

\begin{tabular}{ccccccc}
\hline CLUSTER & A & B & C & D & E & F \\
\hline $\mathbf{C}_{\mathbf{1}}$ & 212,17 & 442,25 & 1018,42 & 853,58 & 1891,25 & 986,17 \\
$\mathbf{C}_{\mathbf{2}}$ & 37,33 & 51,87 & 121,18 & 262,26 & 812,41 & 130,85 \\
$\mathbf{C}_{\mathbf{3}}$ & 26,33 & 34,59 & 72,41 & 138,76 & 309,47 & 91,24
\end{tabular}

Selanjutnya dilakukan kembali langkah 4 sampai 6. Jika nilai centroid hasil iterasi dengan nilai centroid sebelumnya bernilai sama atau nilai centroid sudah optimal serta posisi cluster data desa/kelurahan yang memiliki sarana kesehatan tidak mengalami perubahan lagi maka proses iterasi berhenti, Namun jika nilai centroid tidak sama atau belum optimal serta posisi data desa/kelurahan yang memiliki sarana kesehatan masih berubah maka prosesiterasi berlanjut pada iterasi berikutnya.

Perhitungan manual pada data desa/kelurahan yang memiliki sarana kesehatan diatas didapatkan hasil akhir yang dimana pada iterasi 4 pengelompokan data yang dilakukan terhadap 3 cluster dengan iterasi 4 didapatkan hasil yang sama. Hasil dari kedua iterasi tersebut benilai $\mathrm{C} 1=13, \mathrm{C} 2=17$, dan $\mathrm{C} 3=4$ pada posisi data tiap cluster a, b, c, d, e dan f. Sehingga posisi cluster pada data tersebut tidak mengalami perubahan lagi maka proses iterasi berhenti. Berdasarkan posisi cluster masing-masing data desa/kelurahan yang memiliki sarana kesehatan dan nilai cluster hasil iterasi keempat.

\section{IMPLEMENTASI}


Pada penelitian yang didukung dari hasil pemrosesan dengan menggunakan Software Rapidminer yang dimana hasil akhir akurasi penerapan algoritma K-Means Clustering diperoleh Cluster Model cluster 0: 13 item, cluster 1: 17 item dan cluster 2: 4 item yang dimana jumlah total keseluruhan adalah 34. Untuk melihat nilai akurasi dapat dilihat pada gambar 1. Berikut ini :

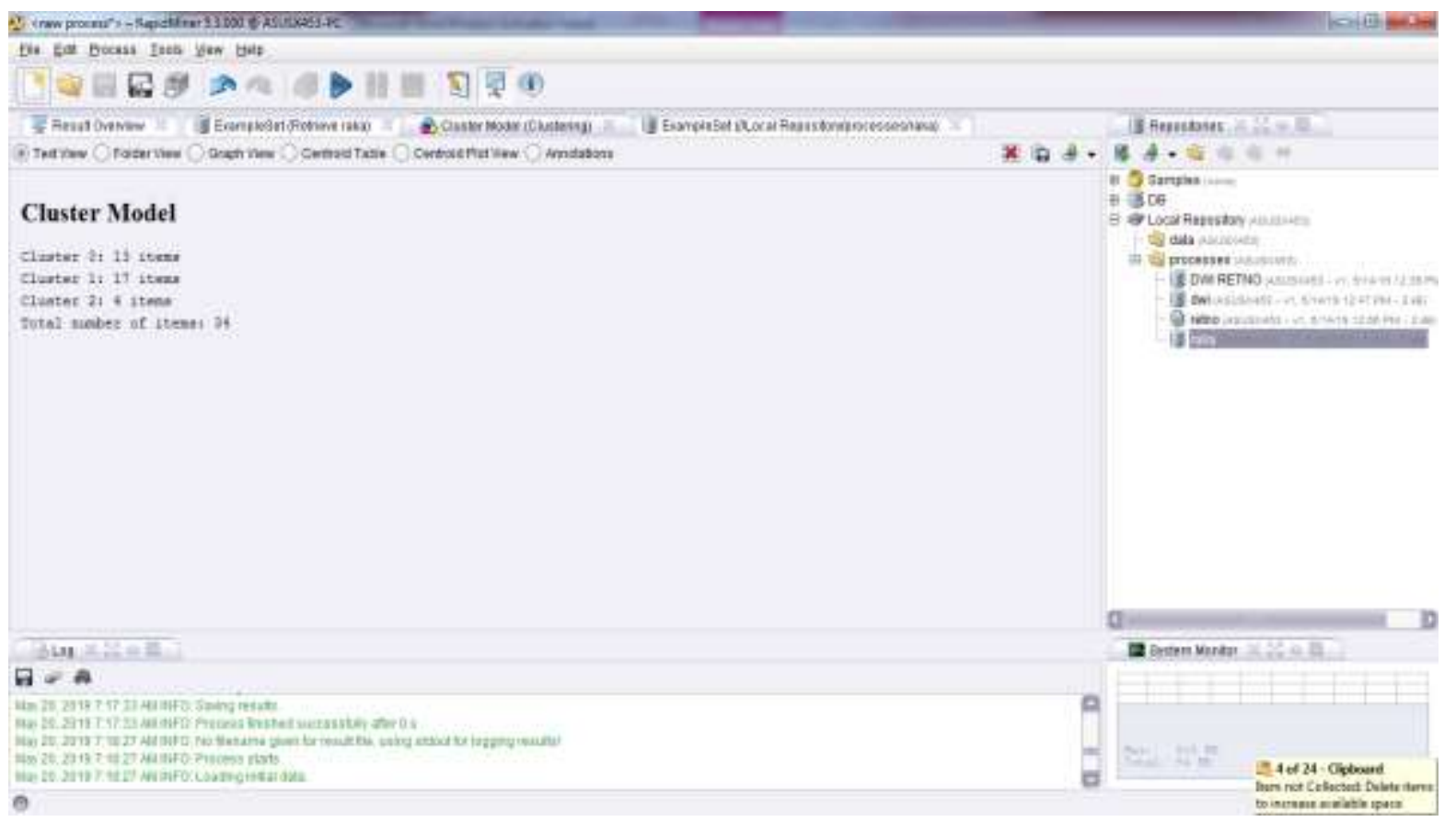

Gambar 4. Data Hasil menggunakan K-Means Clustering

\section{KESIMPULAN}

Hasil akhir penelitian dari jumlah keseluruhan 34 Pronvisi disimpulkan bahwa telah di dapat nilai dengan Cluster Tertinggi, Sedang dan Rendah dalam pengelompokan terhadapat rumah tangga yang memiliki komputer yaitu:

1. (C1) Cluster Sedang dengan jumlah 13 Provinsi yaitu, Aceh, Sumatera Barat, Riau, Jambi, Sumatera Selatan, Lampung, Nusa Tenggara Timur, Kalimantan Barat, Kalimantan Tengah, Kalimantan Selatan, Kalimantan Timur, Sulawesi Selatan, Papua.

2. (C2) Cluster Terendah dengan jumlah sebanyak 17 Provinsi yaitu, Bengkulu, Kep. Bangka, Kepulauan Riau, DKI Jakarta, DI Yogyakarta, Banten, Bali, Nusa Tenggara Barat, Kalimantan Utara, Sulawesi Utara, Sulawesi Tengah, Sulawesi Tenggara, Gorontalo, Sulawesi Barat, Maluku, Maluku Utara, Papua Barat.

3. (C3) Cluster Tertinggi dengan jumlah 4 Provinsi yaitu, Sumatera Utara, Jawa Barat, Jawa Tengah, Jawa Timur.

\section{REFERENCES}

[1] M. Tangkilisan, A. Sorisi, And J. S. B. Tuda, "Peran Sarana Pelayanan Kesehatan Terhadap Kejadian Malaria Di Kecamatan Silian Raya Kabupaten Minahasa Tenggara," J. E-Biomedik, Vol. 3, No. 1, 2015.

[2] A. Saleh, "Klasifikasi Metode Naive Bayes Dalam Data Mining Untuk Menentukan Konsentrasi Siswa ( Studi Kasus Di Mas Pab 2 Medan )," Konf. Nas. Pengemb. Teknol. Inf. Dan Komun., Pp. 200-208, 2014.

[3] R. Setiawan And N. Tes, "Penerapan Data Mining Menggunakan Algoritma K-Means Clustering Untuk Menentukan Strategi Promosi Mahasiswa Baru ( Studi Kasus : Politeknik Lp3i Jakarta )," Vol. 3, No. 1, Pp. 76-92, 2016.

[4] 2015 Surmayanti, Et Al, "Penerapan Analysis Clustering Pada Penjualan Komputer Dengan Perancangan Aplikasi Data Mining Menggunakan Algoritma K-Means," Pros. Semin. Ilm. Nas. Teknol. Komput., Vol. 1, No. Senatkom, Pp. 50-59, 2015.

[5] A. K. Wardhani, "Implementasi Algoritma K-Means Untuk Pengelompokkan Penyakit Pasien Pada Puskesmas Kajen Pekalongan," Vol. 14, Pp. 30-37, 2016. 